\title{
On the Use of Sodium Bicarbonate and Calcium in the Rectification of Sea-Water in Aquaria.
}

\author{
By \\ C. M. Breder, Jr., \\ New York Aquarium, \\ and \\ H. W. Smith, \\ Bellevue Medical College.
}

THE use of sodium bicarbonate for the maintenance of the proper hydrogen ion concentration and bicarbonate content in marine aquaria using a closed circulation, was recommended by Breder and Howley (1). It was pointed out by them that this substance was more suitable for such purposes than quicklime which is used in the Plymouth Aquarium, because the latter " disproportionately increases the calcium content." Atkins (2) disagrees with this opinion chiefly on the grounds that sulphates from metabolized food do not tend to increase the acidity of the water.* Atkins quotes Smith (3) as stating that the urinary $\mathrm{SO}_{4}$ comes from ingested sea-water, and neglects entirely the fact that Smith had reference to the bulk of the urinary salts. As Smith remarks on page 494, a fraction of the urinary $\mathrm{SO}_{4}$ is of metabolic origin, and this fraction is of course the only $\mathrm{SO}_{4}$ which is significant in the problem discussed by Breder and Howley.

The maintenance of a proper hydrogen ion concentration in sea-water depends as much upon the bound $\mathrm{CO}_{2}\left(\mathrm{BHCO}_{3}\right)$ as upon the free $\mathrm{CO}_{2}$, and it was shown by Breder and Howley that the bound $\mathrm{CO}_{2}$, which practically represents the entire buffering capacity of sea-water, tends to be depleted in aquaria water in the course of time. This depletion is due primarily to the oxidation of the protein fed as food to the fishes, and the subsequent excretion by the fishes of neutral sulphates, phosphates, etc. The base with which these acids are neutralised (within the body of the fish) is ultimately drawn from the bicarbonate of sea-water, thus increasing the acidity of the latter (at a given $\mathrm{CO}_{2}$ tension) by lowering the $\mathrm{BHCO}_{3}$. At the same time the fishes are deprived of a salt $\left(\mathrm{BHCO}_{3}\right)$ which is essential to the maintenance of their own alkaline reserve. The metabolism of one pound of meat produces a quantity of sulphuric and phosphoric

\footnotetext{
* Or decrease the alkalinity as Atkins prefers to express it.
} 
acids roughly equivalent to $2 \cdot 5$ grams of $\mathrm{NaHCO}_{3}$, or the quantity contained in 12 litres of sea-water. The restoration of the alkaline reserve $\left(\mathrm{BHCO}_{3}\right)$ by the addition of $\mathrm{NaHCO}_{3}$ (or $\left.\mathrm{Na}_{2} \mathrm{CO}_{3}\right)$ is more rational than by the addition of lime, since the resulting increase in $\mathrm{Na}$ is insignificant in comparison with the quantity originally present, whereas this cannot be said of $\mathrm{Ca}$, of which sea-water contains only a small amount. The original bicarbonate would be entirely replaced in about $2 \frac{1}{2}$ years in the New York Aquarium system. Using $\mathrm{NaHCO}_{3}$ to restore the alkali reserve, the total $\mathrm{Na}$ would be increased only about 0.5 per cent during this time, whereas if lime is used the total $\mathrm{Ca}$ would be increased by more than 10 per cent or 20 times as much in proportion to the natural molar content.

While the practical danger of over-dosage may be not very immediate, for those concerned with the management of public aquaria, it is comforting to have such possibilities as remote as possible. A comparison of the two papers in question clearly shows that the attempt at the New York institution has been aimed at keeping the chemical nature of the stored sea-water more nearly constant than at Plymouth, both by mechanical and chemical means. The degree of accuracy desirable is doubtless of a controversial nature, but in the absence of exact knowledge of the optimum conditions for each species involved, it was deemed best to limit the deviations from natural sea-water as much as possible.

\section{REFERENCES.}

1. Breder, C. M., and Howley, T. H. 1931. The Chemical Control of Closed Circulating Systems of Sea-Water in Aquaria for Tropical Marine Fishes. Zoologica, IX, No. 11, pp. 403-442.

2. Atkins, W. R. G. 1931. Note on the Condition of the Water in a Marine Aquarium. Jour. Mar. Biol. Assoc., N.S., Vol. XVII, pp. 479-481.

3. Sмгтн, H. W. 1930. The Absorption and Excretion of Water and Salts by Marine Teleosts. Amer. J. Physiol., Vol. 93, pp. 480-505. 